\title{
Evaluation of the Fertility and Mortality in Women at Fertile Age
}

\author{
Thaiza Gracielle César da Silva Medeiros, Tainara Lôrena dos Santos Ferreira, \\ Héllyda de Souza Bezerra, Julliane Tamara Araújo de Melo, Thaiza Teixeira Xavier Nobre, \\ Fábia Barbosa de Andrade
}

Trairi Health Sciences College (FACISA in Portuguese), Rio Grande do Norte Federal University (UFRN), Santa Cruz, Rio Grande do Norte, Brazil

Email: thaiza.gracielle@hotmail.com,tainara_lorena@hotmail.com,hellydasbezerra@hotmail.com, tamara_bio@yahoo.com.br, thaizax@hotmail.com,fabiabarbosabr@yahoo.com.br

How to cite this paper: da Silva Medeiros, T.G.C., dos Santos Ferreira, T.L., de Souza Bezerra, H., de Melo, J.T.A., Nobre, T.T.X. and de Andrade, F.B. (2018) Evaluation of the Fertility and Mortality in Women at Fertile Age. Open Journal of Nursing, 8, 139-149.

https://doi.org/10.4236/ojn.2018.82012

Received: July 31, 2017

Accepted: February 11, 2018

Published: February 14, 2018

Copyright $\odot 2018$ by authors and Scientific Research Publishing Inc. This work is licensed under the Creative Commons Attribution International License (CC BY 4.0).

http://creativecommons.org/licenses/by/4.0/

\begin{abstract}
The female population is passing through many transformations as on the familiar life as for the society. This inequality among the genders reflects on the health, mainly, on the women. The women morbidity and mortality surveillance is one of the priorities of the Health Ministry. This worksheet aims to evaluate the fertile women fertility and mortality, from 10 to 49 years old, in Trairi/RN. It is descriptive, ecological and temporary, whose analysis is based on the Mortality Information System data, in a period of 5 years (2010-2014), at the $\mathrm{V}^{\text {th }}$ Public Health Regional Center (URSAP), which embraces the Trairi region, composed by 21 cities, in Rio Grande do Norte. The data processing and analysis were used by the SPSS software. It was observed the mortality coefficient with a decline from $2011(0.84)$ and back to increase in 2014 (0.94). This reveals the necessity of better health actions and monitoring from other factors that may interfere on women health.
\end{abstract}

\section{Keywords}

Mortality, Women Health, Epidemiology

\section{Introduction}

The female population is in social accession for some years, acquiring their right on job, studies and politics, besides doing, most of the time, the house chores. For this reason, the women can feel overloaded and, with this, collaborate so that the sickness factor comes to achieve them, mainly if they are in a fertile age, considered a productive age, what is contributing to the increase of the morbidity and mortality index among the women. 
The female population is passing through many transformations as in the familiar life as for the society. Although all advance, the woman is still put in social disadvantage in relation to the man. This inequality between the genders reflects on health, in special, on the woman [1].

Given this reflex on women's health, it is necessary for a larger attention. To that, the Health Ministry (HM) developed programs to secure those women are assisted and monitored given the diseases that could affect them, mainly, the woman in fertile age. The women in fertile age are the one who is between 10 to 49 years old; internationally, from 15 to 49 years old. In Brazil, this age estimate was created based on the maternal death record, in cases of pregnancy, in younger than 15 years old [2].

This monitoring of the women at the reproductive age and active on the society is necessary for understanding that this clientele needs to be attended, once they have the right to access the information and health.

From this, health programs were created financed by the Unified Health System and turned to the woman, aiming to give them the right to health and to guarantee the assistance in any health service of the public network. This allows the diseases prevention, mainly the programs turned to the tracking of cancers (breast, uterus and ovaries) and prenatal, decreasing the chances to discover a disease in advanced status.

The women morbidity and mortality surveillance is one of the priorities of the Health Ministry to verify the improvement of the life quality. The researches and studies are evaluating and searching to understand the determinants related to the women health, however, a few allow a spread diagnostic about the morbidity profile and mortality of the fertile women [1].

According to the United Nations Organizations in Brazil, one of the tem mainly causes of mortality is the mother's death among women from 10 to 49 years old; however, $90 \%$ of the cases were avoidable. The female morbidity and mortality indexes are presenting higher taxes in the last years, considering that the majority of the mother's death occurs to the fertile women [3].

The most frequent health problems in this clientele are the malignant neoplasias, mainly the cervix and breast cancer; strole; pneumonia, mental and behavioral disorders; hearth diseases; hypertension; heath attack, among other causes [4].

The main death causes of the fertile women in the Brazilian capitals, in 2002, in descending order, were: Stroke, AIDS, murder, breast neoplasm, transport accidents, hypertensive diseases, digestive organs neoplasm, diabetes, ischemic hearth disease and cervix neoplasm, respectively. Those causes, when analyzed in specific places, change the proportion [5].

In this sense, it shall go along the women illness causes and mortality, so that there is prevention of diseases and injuries from the health action offering on the services that compose the Unified Health System network. Another important aspect is linked to the birth aspect, because when there are larger deaths in this 
age, there will be reduction on the population growth.

In this perspective, the mother's mortality is considered a health challenge that leads Brazil, in 2000, sign a commitment to reduce the mortality rate till 2015, what was not achieved, being necessary to review the strategies, once the number of deaths constitutes a good indicator of the social reality [6].

Considering the necessity of an investigation of the women mortality and fecundation in fertile age, this study aims to evaluate the mortality and fecundation in women in fertile age from 10 to 49 years old, in Trairi, Rio grande do Norte, from 2010 to 2014.

\section{Methodology}

It is about a descriptive, ecological and temporal study, in which was realized the data analyzes of the information system about the mortality, in a period of 5 years (2010-2014), from the V public health regional unity (V URSAP in Portuguese), what composes the Trairi region, composed by 21 cities, located in Rio Grande do Norte, Brazil.

The studied population refers to the death occurred from 2010 to 2014, contained and available by the Unified Health System Computing Department (DATASUS in Portuguese). The information contained on the computing department depends on the death declaration properly filled and send to the health secretary. The used population data were the census (2010-2012), available on DATASUS.

To the processing and data analyzes, was used the Statistical Package for Social Sciences software, version 22.0, with series number: 10101141047, through which were analyzed the variables, fecundation and mortality in fertile age women, schooling, marital status and death causes, International Statistical Classification of Diseases and Related Health Problems, ICD, from its chapters, evaluating the mortality index in women in fertile age (from 10 to 49 years old). The mortality coefficient was calculated with the reason among the deaths in fertile women/population with the same age and same gender with a basis of 1000 , besides adopting a convidence interval of $95 \%$ and significance level of $p<$ 0.05 .

This study, for using secondary data, with public domain, didn't need the appreciation of the Research Ethinic Committee.

\section{Results}

In this study, were observed the cities from the $\mathrm{V}^{\text {th }}$ Health Region (HR) in Rio Grande do Norte, Santa Cruz, considering the time series 2010 to 2014, to analysis of the mortality in fertile women, which comprises the age group between 10 to 49 years old.

On Table 1 , it is possible to verify that the mortality coefficient presents a decline from 2011 (0.84) turning to increase in 2014 (0.94). On the other hand the fertility presented a similar behavior to the mortality, with a light decline from 
Table 1. Distribution of the coefficient mortality and fertility in fertile women from the $\mathrm{V}^{\text {th }}$ health region in Rio Grande do Norte, during the time series 2010-2014, V URSAP, Rio Grande do Norte, Brazil, 2016.

\begin{tabular}{cccccc}
\hline & 2010 & 2011 & 2012 & $\mathbf{2 0 1 3}^{*}$ & $\mathbf{2 0 1 4}^{*}$ \\
\hline Mortality coefficient & 0.69 & 0.84 & 0.74 & 0.61 & 0.94 \\
Fertility coefficient & 48.08 & 46.14 & 44.93 & 45.25 & 47.66 \\
\hline
\end{tabular}

${ }^{\star}$ Used the resident population from 2012, because the national estimate didn't fragment by gender and age group.

2011 (46.14) and increase in 2014 (47.66).

Table 2 demonstrates the average, median and standard deviation values and confidence interval (CI). During those years, the average of the higher relevance was in 2014, with 2.62 and, in second place, 2011, with 2.33. The lowest average was in 2013, with 1.71 .

Table 3 demonstrates how took place in this period in each city, the ones with larger index of deaths and which year had the higher relevance. From 2010 to 2012, it kept the same level. In 2013, this index declined and, in 2014, elevated to 55 deaths. In this period, the cities where stranded out are Santa Cruz, following by São Paulo do Potengi and Januário CIcco (Boa Saúde). The highlight to Santa Cruz/RN is related to the fact of being the module main city.

Table 4 demonstrates that there is a percentage in women with less instruction, mainly among the women with schooling from 1 to 3 years. This value is increased during 2011 and 2012, declining in 2013 and turning to relapse in 2014, totalizing from this group 47 women, on the period of 5 years. As for the marital status, it shows that the mortality rate among the single women is larger, what totaled 143 deaths belonging to this group. Thereby, it is understood that the women with less schooling level and singles die more, observing the sociodemographic characteristic of this group.

On Table 5, are demonstrated the 3 main causes of mortality by each year, however in this period stands out the relevance of three groups. In first place, there are the external morbidity and mortality causes with 59 deaths, followed by malignant neoplasm with 51 deaths and, lastly, the diseases of the circulatory system, with 32 of the deaths.

\section{Discussions}

In Brazil, when the health ministry launched the National pact for the mother mortality reduction and neonatal, was established the mother death surveillance and in fertile mother, organizing the investigations [7]. In this way, was encouraged the death notification, aiming to avoid false data and minimize the mistakes.

Table 1 can be seen that the coefficient of mortality is always below 1 . Thereby, shows that, in the period of 5 years, less than 1 woman to each 1000 women died, what means a low index. The fecundation rate is more elevated, 
Table 2. Distribution of the average, median and standard deviation of fertile women deaths in the $\mathrm{V}^{\text {th }}$ Health Region, during the time series 2010-2015, V URSAP, Rio grande do Norte, Brazil, 2016.

\begin{tabular}{cccccc}
\hline Death year & Average & Median & $\begin{array}{c}\text { Standard } \\
\text { deviation }\end{array}$ & CI & P \\
\hline 2010 & 1.90 & 1.00 & 2.38 & $0.82-2.99$ & 0.002 \\
2011 & 2.33 & 1.00 & 2.68 & $1.11-3.56$ & 0.001 \\
2012 & 2.05 & 1.00 & 2.35 & $0.98-3.12$ & 0.001 \\
2013 & 1.71 & 1.00 & 2.64 & $0.51-2.92$ & 0.008 \\
2014 & 2.62 & 2.00 & 2.69 & $1.39-3.84$ & 0.000 \\
\hline
\end{tabular}

Table 3. Distribution of fertile women deaths per cities in $\mathrm{V}$ health region, during the time series 2010-2014, V URSAP, Rio Grande do Norte, Brazil, 2016.

\begin{tabular}{|c|c|c|c|c|c|}
\hline City & 2010 & 2011 & 2012 & 2013 & 2014 \\
\hline Barcelona & - & $2.04 \%(1)$ & - & $2.78 \%(1)$ & $1.82 \%(1)$ \\
\hline Bom Jesus & $2.5 \%(1)$ & $2.04 \%(1)$ & $2.33 \%(1)$ & - & $3.64 \%(2)$ \\
\hline Campo Redondo & $0.0 \%$ & $6.12 \%(3)$ & $6.98 \%(3)$ & $5.56 \%(2)$ & $5.45 \%(3)$ \\
\hline Coronel Ezequiel & $2.5 \%(1)$ & - & - & $2.78 \%(1)$ & $3.64 \%(2)$ \\
\hline Jaçanã & $5.0 \%(2)$ & $4.08 \%(2)$ & $6.98 \%(3)$ & $5.56 \%(2)$ & $3.64 \%(2)$ \\
\hline $\begin{array}{c}\text { Januário Cicco } \\
\text { (Boa saúde) }\end{array}$ & $7.5 \%(3)$ & $14.29 \%(7)$ & $6.98 \%(3)$ & $8.33 \%(3)$ & $3.64 \%(2)$ \\
\hline Japi & $2.5 \%(1)$ & $2.04 \%(1)$ & - & - & $5.45 \%(3)$ \\
\hline Lagoa de Velhos & $2.5 \%(1)$ & $2.04 \%(1)$ & $2.33 \%(1)$ & - & - \\
\hline Lajes Pintadas & $5.0 \%(2)$ & - & $13.95 \%(6)$ & - & - \\
\hline Ruy Barbosa & - & $2.04 \%(1)$ & $2.33 \%(1)$ & - & $1.82 \%(1)$ \\
\hline $\begin{array}{l}\text { Pres.Juscelino } \\
\text { (Serra Caiada) }\end{array}$ & $2.5 \%(1)$ & - & $2.33 \%(1)$ & $2.78 \%(1)$ & $1.82 \%(1)$ \\
\hline Santa Cruz & $27.5 \%(11)$ & $22.45 \%(11)$ & $20.93 \%(9)$ & $33.33 \%(12)$ & $21.82 \%(12)$ \\
\hline Santa Maria & $5.0 \%(2)$ & - & $2.33 \%(1)$ & $2.78 \%(1)$ & $3.64 \%(2)$ \\
\hline São Bento do Trairí & $5.0 \%(2)$ & $2.04 \%(1)$ & $2.33 \%(1)$ & - & - \\
\hline São José do Campestre & $7.5 \%(3)$ & $10.20 \%(5)$ & $4.65 \%(2)$ & $2.78 \%(1)$ & $9.09 \%(5)$ \\
\hline São Paulo do Potengi & $7.5 \%(3)$ & $8.16 \%(4)$ & $11.63 \%(5)$ & $5.56 \%(2)$ & $12.73 \%(7)$ \\
\hline São Pedro & - & $6.12 \%(3)$ & - & $2.78 \%(2)$ & $3.64 \%(1)$ \\
\hline São Tomé & $5.0 \%(2)$ & $6.12 \%(3)$ & $9.30 \%(4)$ & $13.89 \%(5)$ & $5.45 \%(3)$ \\
\hline Senador Elói de Souza & - & $2.04 \%(1)$ & $4.65 \%(2)$ & $5.56 \%(2)$ & $3.64 \%(2)$ \\
\hline Sitio Novo & $2.5 \%(1)$ & $2.04 \%(1)$ & - & $2.78 \%(1)$ & $3.64 \%(2)$ \\
\hline Tangará & $10.0 \%(4)$ & $6.12 \%(3)$ & - & $2.78 \%(1)$ & $5.45 \%(3)$ \\
\hline Total & $100 \%(40)$ & $100 \%(49)$ & $100 \%(43)$ & $100 \%(36)$ & $100 \%(55)$ \\
\hline
\end{tabular}

about 50 women to each 1000 , showing that they are born more than dying.

In Brazil, the factors that hinders the real monitoring of the mother death level 
Table 4. Distribution of the fertile women death, according to the schooling and marital status, during the time series 2010-2014, Rio Grande do Norte, Brazil, 2016.

\begin{tabular}{|c|c|c|c|c|c|c|c|}
\hline & & 2010 & 2011 & 2012 & 2013 & 2014 & Total \\
\hline & None & $14.7 \%(5)$ & $14.7 \%(5)$ & $14.7 \%(5)$ & $41.2 \%(9)$ & $14.7 \%(5)$ & $100 \%(34)$ \\
\hline \multirow[t]{3}{*}{ Schooling } & 4 to 7 & $14.2 \%(4)$ & $32.1 \%(9)$ & $28.5 \%(8)$ & $11.0 \%(3)$ & $14.2 \%(4)$ & $100 \%(28)$ \\
\hline & 8 to 11 & $6.9 \%(2)$ & $31.0 \%(9)$ & $27.5 \%(8)$ & $10.3 \%(3)$ & $24.3 \%(7)$ & $100 \%(29)$ \\
\hline & 12 or more & $16.6 \%(1)$ & $34.4 \%(2)$ & $34.4 \%(2)$ & $0.0 \%(0)$ & $16.6 \%(1)$ & $100 \%(06)$ \\
\hline \multirow{2}{*}{$\begin{array}{l}\text { Marital } \\
\text { status }\end{array}$} & Single & $19.5 \%(28)$ & $24.4 \%(35)$ & $17.4 \%(25)$ & $17.4 \%(25)$ & $21.3 \%(30)$ & $100 \%(143)$ \\
\hline & Married & $19.1 \%(9)$ & $12.7 \%(6)$ & $27.6 \%(13)$ & $10.6 \%(5)$ & $30.0 \%(14)$ & $100 \%(47)$ \\
\hline
\end{tabular}

Table 5. Distribution of the prevalence rate of the death causes in fertile women, international statistical classification of diseases and related health problems: ICD, from its chapters, during the time series 2010-2014, V URSAP, Rio Grande do Norte, Brazil, 2016.

\begin{tabular}{|c|c|c|c|c|c|c|}
\hline Injuries & 2010 & 2011 & 2012 & 2013 & 2014 & Total \\
\hline Chapter I Some infectious and parasitic diseases & $25.0 \%(2)$ & $37.5 \%(3)$ & $12.5 \%(1)$ & - & $25.0 \%(2)$ & $100 \%(8)$ \\
\hline Chapter II Neoplasms & $13.72 \%(7)$ & $15.68 \%(8)$ & $25.49 \%(13)$ & $11.76 \%(6)$ & $33.33 \%(17)$ & $100 \%(51)$ \\
\hline $\begin{array}{l}\text { Chapter III Blood diseases, hematopoietic and } \\
\text { Immunological }\end{array}$ & - & $50.0 \%(1)$ & $50.0 \%(1)$ & - & - & $100 \%(2)$ \\
\hline $\begin{array}{l}\text { Chapter IV Endocrine, nutritional } \\
\text { and metabolic diseases }\end{array}$ & $10.0 \%(1)$ & $20.0 \%(2)$ & $20.0 \%(2)$ & $40.0 \%(4)$ & $10.0 \%(1)$ & $100 \%(10)$ \\
\hline Chapter V Mental and behavioral disorders & - & - & - & $100 \%(1)$ & - & $100 \%(1)$ \\
\hline Chapter VI Nervous system diseases & - & - & - & $100 \%(1)$ & - & $100 \%(1)$ \\
\hline Chapter IX Circulatory system diseases & $18.75 \%(6)$ & $21.87 \%(7)$ & $15.62 \%(5)$ & $18.75 \%(6)$ & $25.0 \%(8)$ & $100 \%(32)$ \\
\hline Capítulo X Respiratory system diseases & $10.0 \%(1)$ & $40.0 \%(4)$ & $10.0 \%(1)$ & $10.0 \%(1)$ & $30.0 \%(3)$ & $100 \%(10)$ \\
\hline Chapter XI Digestive system diseases & $28.57 \%(2)$ & $14.28 \%(1)$ & $42.85 \%(3)$ & - & $14.28 \%(1)$ & $100 \%(7)$ \\
\hline $\begin{array}{c}\text { Chapter XII Skin and Subcutaneous } \\
\text { tissue diseases }\end{array}$ & $50.0 \%(1)$ & - & - & $50.0 \%(1)$ & - & $100 \%(2)$ \\
\hline $\begin{array}{l}\text { Chapter XIII Musculoskeletal } \\
\text { system and conjunctive tissue diseases }\end{array}$ & - & $50.0 \%(1)$ & $50.0 \%(1)$ & - & - & $100 \%(2)$ \\
\hline Chapter XIV Genitourinary system diseases & - & $33.33 \%(1)$ & $33.33 \%(1)$ & - & $33.33 \%(1)$ & $100 \%(3)$ \\
\hline $\begin{array}{l}\text { Chapter XV Pregnancy, } \\
\text { childbirth and postpartum }\end{array}$ & $25.0 \%(1)$ & $25.0 \%(1)$ & - & - & $50.0 \%(2)$ & $100 \%(4)$ \\
\hline $\begin{array}{l}\text { Chapter XVII Congenital malformations, } \\
\text { deformities and chromosomal abnormalities }\end{array}$ & $50.0 \%(1)$ & $50.0 \%(1)$ & - & - & - & $100 \%(2)$ \\
\hline $\begin{array}{c}\text { Chapter XVIII Symptoms, signals and abnormal } \\
\text { finding of clinical and laboratory exams, } \\
\text { not classified in other part }\end{array}$ & $20.0 \%(1)$ & - & $40.0 \%(2)$ & $20.0 \%(1)$ & $20.0 \%(1)$ & $100 \%(5)$ \\
\hline $\begin{array}{l}\text { Chapter XIX Injuries and some } \\
\text { other sequences of external causes }\end{array}$ & $83.33 \%(10)$ & $8.33 \%(1)$ & - & - & $8.33 \%(1)$ & $100 \%(12)$ \\
\hline $\begin{array}{l}\text { Chapter XX Morbidity and } \\
\text { mortality external causes }\end{array}$ & $13.55 \%(8)$ & $25.42 \%(15)$ & $18.64 \%(11)$ & $15.25 \%(9)$ & $27.11 \%(16)$ & $100 \%(59)$ \\
\hline
\end{tabular}


are the sub information, that occurs when there is the omission of the death cause, and the sub-register of the death declaration, what occurs mainly on the North, Northeast, Center-west region, being by the difficulty to access the registry or by not knowing the importance of the death declaration [7].

It can be observed that the average value varied from 1.71 to 2.62 in this period, in 2010 and 2015, respectively; the measure kept stable with 1 and in 2014 elevated to 2 , and in all the studied years, the percentage was less than 0.5 , what shows a big importance to the study.

The mother death, by a long period, was understand as a fatality, however today it is seen as a sensible indicator of life quality, to reveal that the majority of the death could be avoided, beside the mortality not distribute in a homogenous way on the population The high rate of found mortalities are a serious public health problem and are configured as a women and children human right violation, reaching distinctively the Brazilian regions [7].

About the fecundation coefficient (Table 1), was understood a soft fall from 2011 (46.14), increasing back in 2014 (47.66). In Brazil, it was observed that the fecundation still keeps a differential really elevated among women belonging to the extreme categories. Although the fecundation rate of the period has achieved a low level of the reposition between 2000 and 2010, achieving 1.9 sons per women in average, in 2010, according the demographic census, it is not amazing to find relevant variations around this national measure, in front of the heterogeneity and behaviors and differences on the access to the contraceptives means [8].

It is important to highlight that, in 2010,34.0\% of the women from 15 to 49 years old with fertility well above the reposition, about $27.0 \%$ were on the national average (and near the reposition level) and almost $40 \%$ presented a fertility really low (less than 1.3 sons) [8].

Historically, the women health was related only to the maternal health, paradoxically till the emergence of the Women Health Integral Assistance Program (WHIAP), in 1983, by the Health Ministry, when a new attention paradigm to the women health was constructed by the alliance of the women and health professionals [9] [10]. The WHIAP would be responsible to execute promotion and prevention actions in health, related to the pregnancy, contraception methods, sterility, breast and uterus cancer, diagnosis and treatment of sexually transmitted diseases, sexuality, adolescence and climacteric [10].

According to the basic care protocol, women health, the health ministry developed actions focusing on the diseases and injuries, mainly the cervix cancer tracking, to obtain a significant reduction of the mortality incidence and the mortality, since it is estimated that $12.0 \%$ to $20.0 \%$ of the women from 25 to 64 years old had never undergone to the cytopathological exam, that is the tracking exam [11].

On Table 3, it was possible to observe that was occurring an average of 44 deaths, being that, in 2013, this value decreased and elevated in 2014 to 55, 
keeping the larger index of death registered. From the 21 cities that compose this URSAP, in this period of 5 years, stand out Santa Cruz, with the total of 55 deaths; following by São Paulo do Potengi with 21 and Januário Cicco (Boa saúde) with 18. The cities that kept were Campo Redondo, Jaçanã and Tangará with 11 deaths, and the cities that had the lower index were Barcelona, Lagoa de Velhos and Lages Pintadas.

It is possible to understand that some cities didn't register any death, what can suggest underreporting and, thereby, compromise the data values presented, needing that the death declaration are filled with all the data and passed to be inserted on the information system. On the other hand, it is necessary to investigate this death absence was due to a quality of health assistance provided on the referred cities.

About the registered deaths according to the socio demographic schooling data and marital status (Table 3), was perceived that women who studied from one to three years had high mortality index with a total of 47 deaths, highlighting 2014 with 14 deaths, and the one who studied from eight to eleven years also stood out with 29 deaths.

According to the marital status, it was notorious the death index, in this period, stood out with 143 deaths of the total, being from this total 35 referring to 2011, following for 2014, with 30 deaths of single fertile women. There by, it is understood that single women are the public with higher risk of mortality in relation to other marital status.

According to this study [11], regarding the victims who are 15 or older, in Brazil, 53\% had till eight years of study and $23 \%$ had eight or more years old study. However, stands out that, to $25 \%$ of women death with 15 years or older, the information about the schooling is ignored. A more elevated proportion of victims with less schooling were observed on Northeast region (60.0\%).

Regarding the mortality causes, according to what was presented on Table 4, the main mortality causes in fertile women are on the Chapter XX Morbidity and mortality external causes, with 59 deaths registered in this period. In this chapter, are encompassed the aggressions, the indeterminate cause events and accidents. During the data processing, it was noticed that the accidents were responsible to increase the death value referring to this chapter. Then, stands out the malignant neoplasm, with 51 of the total death in this period, what takes us to think that even with the health politics turned to the women, mainly in disease prevention, there are still many incidents, mainly the malignant neoplasm and specific organs. The diseases from the circulatory system also stands out with 26 of the deaths, among which are present the hearth disease, hypertensive and cerebrovascular diseases.

It is necessary to know the amplitude of the women mortality per aggression and its distribution on the regions and states to the subsidies development so that the State and the society can gather effort on the combat to the violence against the women in Brazil. Another important point is regarding the use of the 
information in the country, aiming to obtain more accurate estimates on those events. On the other hand, following certain injuries, those rates are still underestimated by the information system. Those problems are listed in bad cover (deaths underreporting), deficiency on the quality (deaths registered with poorly defined causes or non specific), what contributes to the underestimation of the mortality rates [11].

Thereby, we must consider gender as one of the main health determinants, necessary on the formulation of public policies [12]. In this sense, the fortification on the feminist movement enabled the women the debate about their right, independent of the maternal reproductive functions. A consequence of this was the creation of the Women Health Total Care Program (WHTCP), elaborated by the Health Ministry. The WHTCP represented a mark to the women health assistance in the country, helping to spread the attention and the access of the women to the health services, as well as an assistance that considers, besides the gestation condition, prenatal and postpartum, other aspects of the women life, as the sexual health, cancer prevention and mental health [13].

In what concerns the gender discussions, it is necessary to scale out that to the women always was reserved to the private space, as for men the public sphere. The political activism space, the wealth production, the university academy, among many others, always was destined to the men, since the socialization process. Linked to this, refers to the feminist women trajectory, that during this history, were protagonist on the denaturalization process of the oppression relation that they lived, as for the own gender or for the sexual orientation [14].

Thus, it is necessary that the health service are prepared to receive the women through a quality reception, a tool that, when incorporated to the health care, can contribute to its success. Therefore, the implementation of the reception on the health services is encouraged, aiming better results obtaining, observed through the well-being reported by users and better indicators of the services offered on the health centers.

\section{Conclusions}

Based on the approached data, we can observe that the women health needs a better monitoring of the health services, considering the epidemiological injuries, as well as other socio demographic factors, inherent to the health-disease process. Related to the limitations of this study, we highlight the presence of underreporting in information systems and failure to fill in correctly, facts that compromise information; however, training and monitoring measures have been constantly implemented to reduce such events.

In this sense, as the positive aspect, the fecundity rate can be noticed in constant situation, reflecting the balanced growth of the population from Trairi region. On the other hand, some elements have proved to be negative, as the coefficient mortality in fertile women revealed a fall following by growth in 2014. Besides that, the association with the low schooling of the women who died and 
the fact that the majority was single reveals a better investigation and awareness of those indicators. Another aspect that calls our attention is the growth of the death external causes.

It is known that the public policies have been improving those indicators, but more incentives are still necessary that exceed the health aspect, showing the understanding of the fertile women mortality as a multi factorial question, which involves a social and community education process, aiming to reduce the violence against the women and accomplish the integral right to be assisted on the health services. This passes still for an inclusive and cozy understanding by the health professionals and the city and state health managers, turning the universal right effective, equitable and integral recommended by the health Brazilian system.

\section{References}

[1] Ferreira, D.L. and Pires, V.A.T.N. (2013) Profile of Morbidity and Mortality at Women in Fertile Age on the Scoop of the Health Region in Ipatinga. Integrated Nursing Magazine, 6, 1119-1132.

[2] Health Ministry (BR) (2007) Maternal Mortality Committee Manual. Health Ministry, Brasília. $\underline{\text { http://bvsms.saude.gov.br/bvs/publicacoes/comites_mortalidade_materna_3ed.pdf }}$

[3] United Nations in Brazil (UNBR) Maternal Mortality Causes and High Index of Deaths from the UNFPA Forum in Salvador. News Published in August ${ }^{\text {th }}, 2012$. http://www.onu.org.br/causas-da-mortalidade-materna-e-alto-indice-de-obitos-sao -temas-de-forum-da-unfpa-em-salvador/

[4] Gomes, K.R.O. and Tanaka, A.C.A. (2003) Referred Morbidity and Health Services Use by Working Women, Sâo Paulo. Public Health Magazine, 37. http://www.scielo.br/scielo.php?script=sci_arttext\&pid=S0034-89102003000100012 \&lng=en\&nrm=iso

[5] Health Ministry (BR) (2006) Study of Women Mortality from 10 to 49 Years Old, with Emphasis on the Maternal Mortality. Health Ministry, Brasília. https://www.nescon.medicina.ufmg.br/biblioteca/imagem/2041.pdf

[6] Ferraz, L. and Bordignon, M. (2012) Maternal Mortality in Brazil: A Reality that Needs to Change. RBSP, 36, 527-538.

[7] Health Ministry (BR) (2004) Health Care Secretary. Department of Strategically Programmed Actions. National Pact by the Maternal and Newborn Mortality. Health Ministry, Brasília. http://www.saude.ba.gov.br/dab/Pacto_Aprovado_na_tripartite.pdf

[8] Berquó, E.S. and Cavenaghi, S.M. (2014) Notes about the Diferential Educational and Economic of the Fertility in Brazil. R. bras. Est. Pop., 31, 471-482.

[9] Osis, M.J.D. (1998) PAISM: A Milestone on the Reproductive Health Approach in Brazil. Cad. Public Health, 14, 25-32.

[10] Costa, A.M. (1999) PAISM Developing and Implementation in Brazil. In: Giffin, K. and Costa, S.H., Orgs., Reproductive Health Questions, FIOCRUZ, Rio de Janeiro, $468 \mathrm{p}$.

[11] Planning Ministry, Budget and Management (BR) and Institute for Applied Economic Research (IPEA) (2016) Women Mortality per Aggressions in Brazil: Profile and Corrected Estimate (2011-2013). IPEA, Brasília. 
[12] Health Ministry (BR) (2008) Women Policies Especial Secretary. II National Plan of Women Policies. Women Policies Especial Secretary, Brasília.

[13] Health Ministry (BR) (1984) Integral Assistance to the Women Health. Programmatic Basis Action. Documentation Center, Brasília.

[14] Alves, L., Araujo, C. and Cordeiro, I. (2012) Gender Relations and Sexual Diversities: The Lesbian Women Opression. $17^{\text {th }}$ National Meeting of the Female Network and North and Northeast of Studies and Research about the Women and Gender Relations. 